\title{
Epidemiological characterization and risk evaluation associated with the presence of Megninia spp. in posture farms
}

\author{
Tiago Mendonça de Oliveira ${ }^{1^{*}}$ Cristina Mara Teixeira ${ }^{2}$ Thiago Luiz Mendes Arcebispo ${ }^{1}$ \\ Karla Dias Antunes ${ }^{1}$ Leandro do Carmo Rezende ${ }^{3}$ Lucas Maciel Cunha $^{4}$ \\ Soraia de Araújo Diniz ${ }^{1}$ Marcos Xavier Silva ${ }^{1}$
}

\author{
'Escola de Veterinária, Universidade Federal de Minas Gerais (UFMG), 31270-901, Belo Horizonte, MG, Brasil. E-mail: tiago0725@gmail.com. \\ Corresponding author. \\ ${ }^{2}$ Fundação Ezequiel Dias (FUNED), Belo Horizonte, MG, Brasil. \\ ${ }^{3}$ Ministério da Agricultura, Pecuária e Abastecimento (LANAGRO-MG), Pedro Leopoldo, MG, Brasil. \\ ${ }^{4}$ Universidade Federal de Ouro Preto (UFOP), Ouro Preto, MG, Brasil.
}

\begin{abstract}
This study was accomplished with the aim to evaluate and to characterize the risks for the presence of Megninia spp. in poultry farms from Minas Gerais, using for that Correspondence Analysis (CA). A secondary database was used and adapted for this study, with information from 402 chicken houses of 42 laying hens commercial properties. Variables used to compose the correspondence model were selected through tests of Qui-square being considered the significant result of $\mathrm{P} \leq 0,05$. A risk index was built to the presence of Megninia spp. starting from variables considered as risk factors for the presence of those ectoparasites. The CA graph produced for the epidemiological characterization of the presence of Megninia spp. presented an accumulated qui-square value of 58,55\%. There was an association of the risk index with the age ranges of the poultry, among the presence Megninia spp. and the use of mineral oil and acaricide in the ration and; finally, an association between the ruddy ground-dove (Columbina talpacoti) presence and the absence of mites of the Megninia genus. The results supply knowledge on the epidemiology of Megninia spp. In addition, these information can contribute in the decision, reducing the risks of possible infestations in poultry farms and the negative effects of that parasitism.
\end{abstract}

Key words: Megninia spp., risk index, correspondence analysis.

Caracterização epidemiológica e avaliação de risco associados à presença de Megninia spp. em granjas de postura

RESUMO: Este estudo foi realizado com o objetivo de avaliar e caracterizar os riscos para a presença de Megninia spp. em galpões de granjas de postura de Minas Gerais, utilizando para isso Análise de Correspondência (AC). Foi utilizado um banco de dados secundário e adaptado para este estudo, com informações de 402 galpões de 42 propriedades comerciais de galinhas poedeiras. As variáveis utilizadas

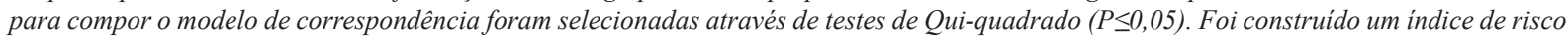
para a presença de Megninia spp. a partir de variáveis consideradas como fatores de risco para a presença desses ectoparasitos. O gráfico da AC produzido para a caracterização epidemiológica da presença de Megninia spp. apresentou um valor de qui-quadrado acumulado de 58,55\%. Observa-se que houve uma associação do índice de risco com a faixa de idades das aves, entre a presença Megninia spp. e a utilização de óleo mineral e de acaricida na ração e, por último, uma associação entre a presença de rolinhas (Columbina talpacoti) e a ausência de ácaros do gênero Megninia. Estes resultados fornecem conhecimento sobre a epidemiologia de Megninia spp. Além disso, estas informações poderão contribuir na tomada de decisão diminuindo os riscos de possíveis infestações nos plantéis e dos efeitos negativos decorrentes por esse parasitismo.

Palavras-chave: Megninia spp., indice de risco, análise de correspondência.

\section{INTRODUCTION}

Among the arthropods, ectoparasites of domestic and wild birds are the group of mites that feed only of feathers or dead skin cells (PROCTOR, 2003; TUCCI, 2005; POUCKE, et al., 2016). These mites are among the most abundant and diversified arthropods of permanent life in the poultry, with more than 2400 species described in the whole world, which is supposed to represent only $20 \%$ of the total number of existent species (MIRONOV, 2003). The non-hematophagous mites of the Megninia 
genus (Suborder Astigmata, Family Analgidae) are included in this group.

In the industrial layer hens, the species of the genus Megninia are important and responsible ectoparasites for damages in the eggs' production, being also told in other hosts, as parakeets, turkeys and pigeons (GUIMARÃES et al., 2001; TUCCI et al., 2005; REZENDE et al., 2013). These mites can bring consequences as appearance of lesions caused by the saliva, which result in pruritus and may trigger secondary lesions such as pyodermatitis (TUCCI et al., 2005).

Occurrence of Megninia spp. in laying chickens can vary according to the climatic and geographical conditions, varying from $2,6 \%$ in Israel (MUMCUOGLU \& LUTSKY, 1990) to 89,6\% in Cuba (HERNÁNDEZ et al., 2006). In Brazil, REZENDE et al. (2015) observed an occurrence of $18,09 \%$ of mites of the Megninia genus in chicken houses of poultry farms posture in the state of Minas Gerais.

In an outbreak of Megninia spp. in an industrial poultry farm located in the state of São Paulo - Brazil, it was verified that the infestation caused around $20 \%$ of reduction in the eggs' production. Besides, was observed the presence of a serous fluid responsible by forming a crust in the lesions, what could provide the occurrence of secondary infection and possible bacterial, fungus contaminations (TUCCI et al., 2005). The species Megninia ginglymura (Mégnin 1877) has already presence notified in the states of São Paulo, Ceará, Rio de Janeiro and Minas Gerais, while Megninia cubitalis (Mégnin 1877) it was already reported in Bahia, Rio Grande do Sul, São Paulo, Ceará and Minas Gerais (GUIMARÃES et al., 2001; REZENDE et al., 2015).

Considering the economic, productive and sanitaries damages for the commercial laying hens industry can be attributed to the ectoparasitism by Megninia spp., the present research has the aims to develop a risk index and to accomplish the epidemiological characterization of the presence of those mites using for that the CA.

\section{MATERIALS AND METHODS}

This research was accomplished starting from an adapted secondary database of CUNHA (2013) and structured with information on the presence and absence of ectoparasites, characteristics from the chicken houses, the poultry, the facilities, the geographical location and the management.

The selection of farms and stratification of the samples was accomplished being taken into account the proportion of existent industrial poultry properties of laying in each one of Administrative Regions of the Agricultural Institute of Minas Gerais (IMA).

A database was built with information from 402 chicken houses of 42 commercial properties from the state of Minas Gerais to evaluate some epidemiological aspects that could characterize the presence of Megninia spp. in the chicken houses of the poultry farms, using for that CA. The present variables in the database went dichotomized to the accomplishment of that analysis.

A risk index was built to characterize the presence of the mites of the Megninia genus and, for that, the risk factors were considered described by REZENDE et al. (2015). In the construction of the risk index a score was attributed for the risk variables (importance 1) and of protection (importance 0). Besides for variables that presented three categories as the interval of removal of dejections, poultry age and number of poultry for cages, the importance was related to the risk that each one would act for the presence of Megninia spp. in the chicken houses of the poultry farms. From this, the result was possible to classify the risk for the presence of those ectoparasites in three categories (low, moderate and high). Variables used for the construction of the risk index for the presence of Megninia spp. are showed in the table 1 .

The variables that would compose the correspondence model were selected starting from a screening through the Pearson's qui-square test $(P \leq 0,05)$. The selected variables were submitted to $\mathrm{CA}$ to evaluate the possible associations among the presence of Megninia spp. with the risk index through graphic figures. The evaluation and interpretation of the graphs was made by evaluating the proximity of the variables with the variable answer, that is, the risk index. Besides, it was considered the intensity of associations with values of accumulated inertia above $40 \%$ according to MINGOTI (2005) and DINIZ (2015) reached in the analyses. For the accomplishment of the selection of variables and for the graphic construction for correspondence in three axes the software Stata ${ }^{\circledR} /$ SE 12.0 was used (STATA CORP, 2012).

Also a study of space analysis of chicken houses was accomplished with the presence of Megninia spp. with use of Kernel map. In this way, the intensity of the presence of that ectoparasite was analyzed in chicken houses of the poultry farms. For that, the software QGIZ 2.18.1 was used (NANNI, 2016) that made possible the georeferencing of the counties that presented chicken houses with the presence of those ectoparasites in the state of Minas Gerais (Figure 1). 
Table 1 - Variables used in the construction of the risk index for the presence of Megninia spp. in the chicken houses of poultry farms in the state of Minas Gerais.

Risk Index

Use or not of mineral oil in the chicken houses

IMA administrative regions of the Minas Gerais

Type of removal of dejections (manual or by mat)

Number of chickens by cage: 1 ( $0-8$ poultry), 2 ( $9-16$ poultry) e 3 (more de 17 poultry)

Age of the poultry: $1(98$ - 382 days), 2 (383 - 667 days), 3 (668 - 1047 days)

Presence or absence of subsistence chickens in the adjacencies of the chicken houses

Interval of removal of dejections: 1 ( 0 - 168 days), 2 (169 - 336 days) e 3 (337 - 560 days)

\section{RESULTS AND DISCUSSION}

The risk index is a tool that can be used to predict possible variables associated to the presence of Megninia spp. Besides, it make possible to qualify and to classify certain conditions predisposing for the occurrence of those mites in a graphic head office.

The appraised variables in the graph of $\mathrm{CA}$ are contained inside of the blue circles (Figure 2). Age of the poultry was associated to the three risk indexes (Figure 2). Besides, the presence of the non-hematophagous mites of the genus Megninia was associated with the control measures, as the use of mineral oil and acaricide in the ration. Also, an association is observed among the ruddy ground-dove (Columbine talpacoti) presence with the absence of Megninia spp. and non use of mineral oil. Risk indexes evidenced the profile of the farms that possess at their chicken houses these mites in the state of Minas Gerais. Besides, the knowledge of such characteristics could evidence aspects of the epidemiology of the infestations for those mites, as well as to contribute in the implementation of measures that could prevent or even reducing the occurrence Megninia spp. in chicken houses of poultry farms in the state of Minas Gerais. The graph produced to characterize the presence of those nonhematophagous mites presented an accumulated quisquare value of $58,55 \%$. Variables used in the graphic construction of correspondence are in the table 2 with their respective legends and abbreviations.

High risk for the presence of Megninia spp. in the chicken houses of the poultry farms was made of the association with the age 1 (98 - 382 days), that is, young poultry are hosts with larger risk of infestations for that ectoparasite. This resulted agree with the result that was observed in Cuba, in which was verified that poultry with approximate age of 39 weeks were more susceptible to the infestations (HERNÁNDEZ et al., 2007).

The moderate and low risk were associated; respectively, with the ranges of age of the poultry 2 (383. 667 days) and poultry 3 (668. 1047 days). Result observed between the association of the age of the poultry and the presence of the nonhematophagous mites of the Megninia genus, may be justified according to some reports and descriptions of the literature, in what was verified that the age of the poultry is a predisposing factor for the appearance of microbial and parasitic diseases (SCHOULER et al., 2012; CEOLIN et al., 2012). In CA, it was observed that, as the poultry got old, risks of parasitism for Megninia spp. decrease and, such result possibly is related to the immunological answers of the host, which began to control the population of that mite. Similar result was observed by MULLENS et al. (2009), who evaluated the spread of $O$. sylviarum in poultry houses. In the same research, the author observed that the intensity and prevalence of that mite increased quickly from 4 to 8 weeks and, after the infestation intensity decreased and the prevalence stayed high, probably to the immune answer of the poultry. Part of the farms can present in their flocks poultry with varied ages in their chicken houses, increasing the risk for the presence and possible infestations for those mites in these establishments.

The presence of Megninia spp. was associated with control measures, as the use of mineral oil and acaricide in the ration. Results corroborated partially with other present studies in the literature that described the use of the aspersion of oils for the insects control, mites and other agricultural plagues.

This products are not used directly for the control of Megninia spp. due, among other reasons, to the difficulty of diagnosis of the parasitism for the farmer in little severe infestations. However, 


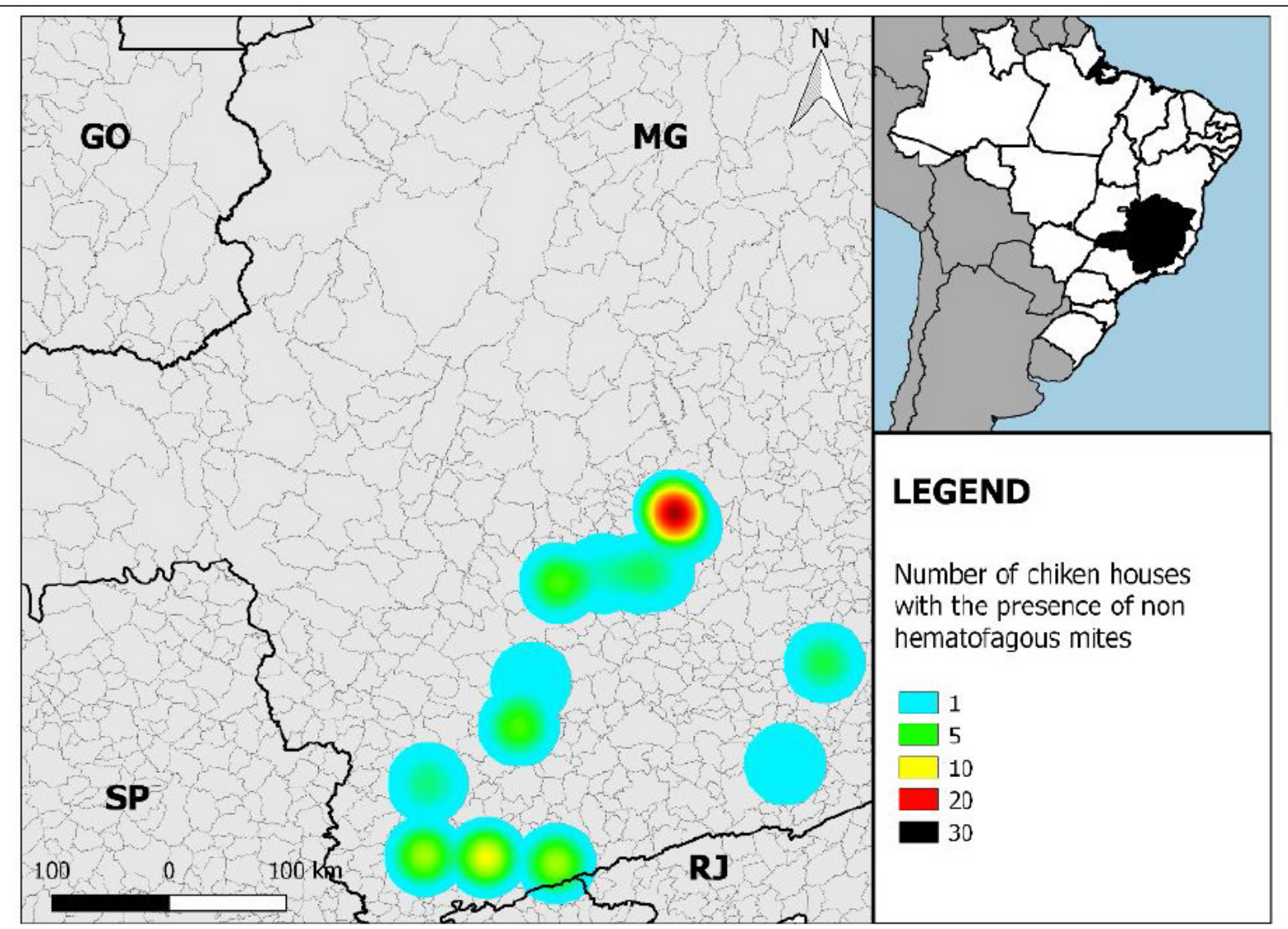

Figure 1 - Municipalities that have chicken houses with the presence of Megninia spp. in the state of Minas Gerais, Brazil, 2012.

these control methods are targeted to control hematophagous mites (D. gallinae, O. bursa and $O$. sylviarum) that are visualized easily on the poultry and in the poultry facilities. As in some research there are acaricide and the mineral oil application, they can take the reduction of the mites populations of Megninia genus and underestimate the occurrence of the same ones in the chicken houses of poultry farms (MAURER et al., 2009; REZENDE et al., 2015). The present study agreed also with REZENDE et al. (2015), who verified that chicken house which used mineral oil had six times less chance of occurrence of mites infestations with Megninia genus than those that didn't use.

The acaricide use in the ration is not now the most appropriate technique to combat infestations for ectoparasites in Brazil, because there are no products recommended by the Ministry of Agriculture, Livestock and Food Supply that they can be used in the ration, being registered only products in the environment application or in the poultry. Therefore, it is not known which would be the possible impacts of handling for the health of the poultry and for the quality of the eggs produced in relation to the daily consumption of acaricide in the ration.

An association was verified between the ruddy ground-dove (Columbina talpacoti) presence and the absence of Megninia spp., such fact, was also observed by REZENDE et al. (2015) when accomplishing the selection procedures with statistics univariate to evaluate the predisposing factors for the occurrence of infestations for those mites. These authors obtained a result that indicated less chance of occurrence of those ectoparasites when there were reports of the ruddy ground-dove presence. However, such a study considered this discovery as a confounding variable, resulting in the exclusion of the same in the final logistic models, in function of the inexistence of reports of this nature for the literature. Besides an epidemiological indicator, this study suggested that the presence of the ruddy grounddove (C. talpacoti) in the adjacencies of the chicken 


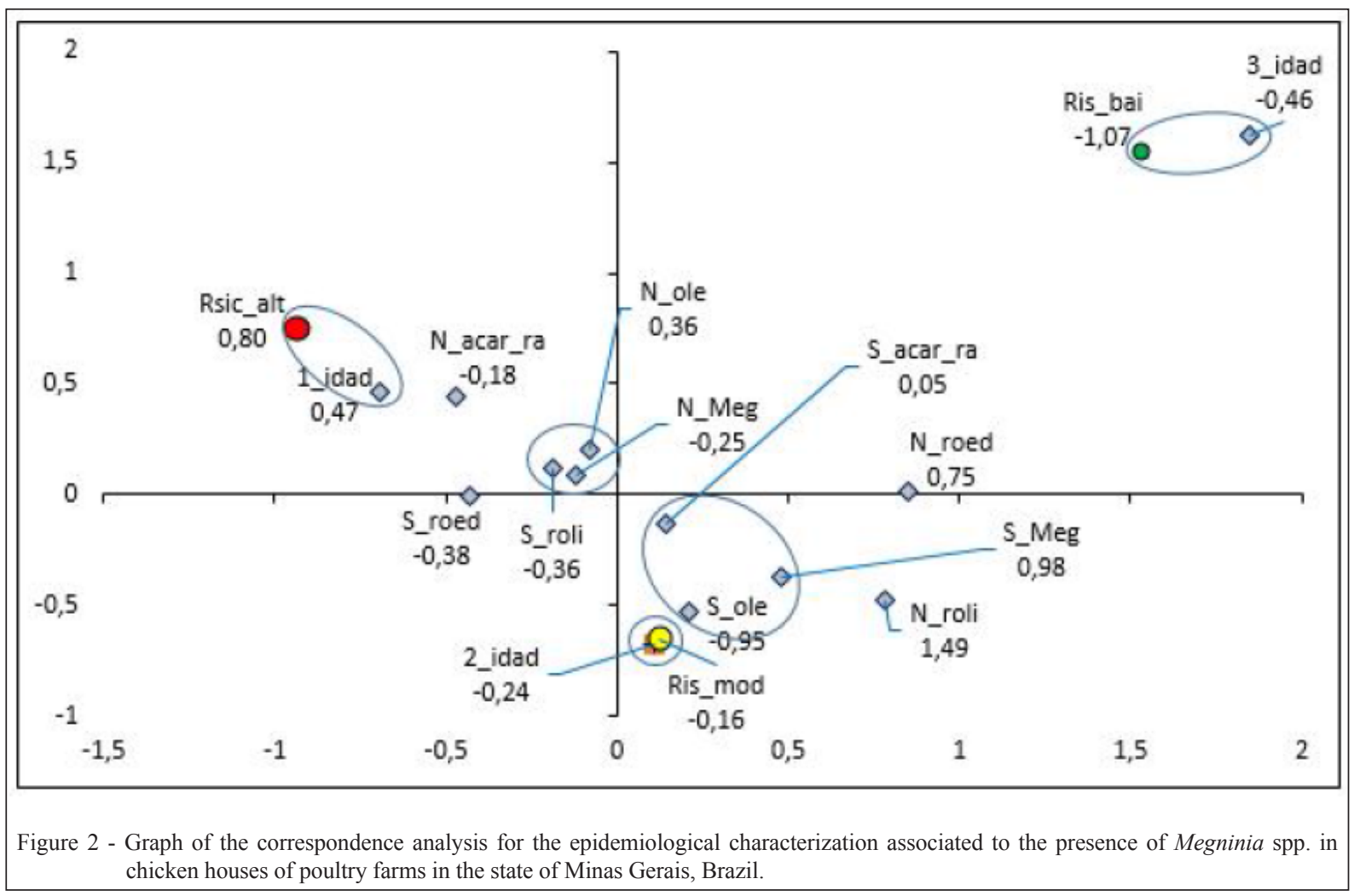

houses of the poultry farms could be classified as a protection factor for the presence of Megninia spp. These birds presented competitive characters, preventing the presence of other species that could be carriers or hosts of this mite. There are no reports in the literature that justify such statement and, this way, it is necessary a new study that can assess the actual characteristics of this association.

The municipalities with chicken houses detected the presence of mites of the Megninia genus are represented in the figure 1. The presence of cluster points was observed in the South Mesoregion/ Southwest of Minas Gerais and in the Metropolitan Mesoregion of Belo Horizonte that possess chicken houses with the presence of those ectoparasites. The variations among the patterns of the points presented in the map of Kernel, the climatic conditions can be attributed, with relative relevance for the geographical location of the non-hematophagous mites of Megninia genus. Located municipalities where the temperature ranges are higher with dry climates didn't present the presence of those ectoparasites in the chicken houses; however, places with mild temperatures possessed them. This report was also described according to REZENDE et al. (2015) which verified that areas of hot climate in the state of Minas Gerais didn't possess those mites, the administrative regions of IMA with high chances of occurrence of Megninia ssp. are in areas with humid climate and mild meridionally.

Another relevant aspect that may contribute to the distribution of the geographical points of the mites of Megninia genus in the state of Minas Gerais was the association demonstrated in CA with poultry age. In this way, areas with farms that possess flock with ages very diversified and with younger poultry, are subjected to present in their chicken house Megninia spp.

\section{CONCLUSION}

The characteristics related to poultry, to chicken houses environment and the mites of Megninia genus were analyzed and they presented results that allowed to qualify them as important aspects in the epidemiology of the presence of those parasites in poultry farms of posture.

It was verified that the age ranges of the poultry was associated with the risk indexes for presence of Megninia spp., demonstrating that young poultry are more susceptible to the parasitism 
Table 2 - Legend of the present variables in the graph of correspondence analysis for non-hematophagous mites (Megninia spp.)

\begin{tabular}{|c|c|}
\hline Variables used in the correspondence model & Abbreviations \\
\hline Age of the poultry 1 ( $98-382$ days $)$ & 1_idad \\
\hline Age of the poultry $2(383-667$ days $)$ & 2_idad \\
\hline Age of the poultry $3(668-1047$ days $)$ & 3_idad \\
\hline No acaricide use in the ration & N_acar_ra \\
\hline Acaricide use in the ration & S_acar_ra \\
\hline No use of mineral oil use in the chicken houses & N_ole \\
\hline Use of mineral oil use in the chicken houses & S_ole \\
\hline Absence of rodents in the chicken houses & N_roed \\
\hline Presence of rodents in the chicken houses & S_roed \\
\hline Absence of ruddy ground dove in the adjacencies of the chickens houses (C. talpacoti) & N_roli \\
\hline Presence of ruddy ground dove in the adjacencies of the chickens houses ( $C$. talpacoti) & S_roli \\
\hline Absence of non-hematophagous mites in the chicken houses (Megninia spp.) & N_meg \\
\hline Presence of non-hematophagous mites in the chicken houses (Megninia spp.) & S_meg \\
\hline Low risk for presence of ectoparasites & Ris_bai \\
\hline Moderate risk for presence of ectoparasites & Ris_mod \\
\hline High risk for presence of ectoparasites & Ris_alt \\
\hline
\end{tabular}

for those mites than the old poultry. Besides, the relevance of the construction of the risk indexes was evidenced as important tools for understanding of the epidemiology of the megninioses in laying hens.

The use of mineral oil and acaricide can reduce the chances of Megninia spp. infestation; although, the target parasite is not necessarily this mite. Eventually, control measures and monitoring of young poultry are important strategies for decreasing risk of the presence of those mites in the chicken houses of posture poultry farms.

Ruddy ground-dove (C. talpacoti) presence in the adjacencies of the chicken houses can be classified as a protection factor for the presence of Megninia spp., and for confirmation of that hypothesis, new studies should be carried out.

\section{ACKNOWLEDGEMENTS}

The authors are grateful to the Conselho Nacional de Desenvolvimento Científico e Tecnológico (CNPq), $\mathrm{N}^{\circ} 131325 / 2016-7$

\section{REFERENCES}

CEOLIN, L.V. et al. Macroscopic and microscopic diagnosis of Aspergillosis in poultry. Acta Scie Veter, v.40, n.3, p.1061, 2012. Available from: <http://revistas.bvs-vet.org.br/actascivet/article/ view/32586/36268>. Accessed: Nov. 12, 2016.

CUNHA, L.M. Aspectos epidemiológicos relacionados à ocorrência de ácaros hematófagos em granjas comerciais de postura no Estado de Minas Gerais e avaliação de armadilhas para captura de Dermanyssus gallinae (Acari: Dermanyssidae) (De Geer, 1778). 2013. 65f. Tese (Doutorado em Ciência Animal) - Escola de Veterinária, Universidade Federal de Minas Gerais. Available from: <http://www.bibliotecadigital.ufmg.br/dspace/ handle/1843/BUBD-9BGJZE>. Accessed: Oct. 20, 2016.

DINIZ, S.A. Avaliação de risco à presença de resíduos de avermectinas na carne bovina sob Inspeção Federal associada às práticas de produção pecuária no Brasil entre 2002-2013. 2015. 81f. Tese (Doutorado em Ciência Animal) - Escola de Veterinária, Universidade Federal de Minas Gerais. Available from: <http://www.bibliotecadigital.ufmg.br/dspace/handle/1843/ SMOC-9VTPKE $>$. Accessed: Oct. 10, 2016.

GUIMARÃES, J.H. et al. Ectoparasitos de importância veterinária. São Paulo: Plêiade/FAPESP, 2001. 218 p.

HERNÁNDEZ, M. et al. Ectoparasites diagnosed in laying hens from comercial farms in Cuba. Information of the presence of a new mite from the feathers (Acari: Analgidae) Megninia. Rev Cub Cienc Avic, v.30, n.1, p.49-54, 2006. Available from: <http:// agris.fao.org/agris-search/search.do? recordID $=$ CU2010700070 $>$. Accessed: Dec. 16, 2016.

HERNÁNDEZ, M. et al. Dynamics of the parasitic population: Megninia ginglymura Mégnin (Acari; Analgidae) modeling criteria. Rev Cub Cienc Avic, v.31, n.2, p.127-134, 2007. Available from: <http://agris.fao.org/agris-search/search. do? recordID=CU2010700022 $>$. Accessed: Dec. 12, 2016

MAURER, V. et al. In vitro efficacies of oils, silicas and plant preparations against the poultry red mite Dermanyssus gallinae. Exp Appl Acarol, v.48, n.1-2, p.31-41, 2009. Available from: <https:// link.springer.com/article/10.1007\%2Fs10493-009-9254-2>. Accessed: Nov. 30, 2016. doi: 10.1007/s10493-009-9254-2.

MINGOTI, S.A. Análise de dados através de métodos de estatística multivariada - uma abordagem aplicada. Belo Horizonte: UFMG, 2005. Cap. 8, p. 257 - 267. 
MIRONOV, S.V. On some problems in the systematics of feather mites. Acarina, v.11, n.1 p.3-29, 2003. Available from: <http:// http://www.federmilben.de/pdf/mironov_2003_problems_in_fm_ proof.pdf>. Accessed: Sept. 15, 2016.

MULLENS, B.A. et al. Temporal changes in distribution, prevalence and intensity of northern fowl mite (Ornithonyssus sylviarum) parasitism in commercial caged laying hens, with a comprehensive economic analysis of parasite impact. Vet Parasitol, v.160, n.1-2, p.116-33, 2009. Available from: <http://www.sciencedirect.com/ science/article/pii/S0304401708005980?via\%3Dihub>. Accessed: Nov. 25, 2016. doi: 10.1016/j.vetpar.2008.10.076.

MUMCUOGLU, K.Y.; LUTSKY, I.A. Prevalence survey of poultry house mites in Israel. Acaralogia, v.31, n.1, p.51-56, 1990 Available from: <http://www1.montpellier.inra.fr/CBGP/acarologia/ export_pdf.php?id=2489\&typefile=pdf $>$. Accessed: Sept. 10, 2016.

NANNI, A.S. et al. QGIS - Versão 2.18.1 Software gratuito Accessed: Nov. 20, 2016. Online. Available from: <http://www. qgis.org/en/site/>.

POUCKE, S.V. et al. Megninia ginglymura feather mite infestation in a Hamburg poultry flock in the United Kingdom. Vet Dermatol, v.27, p.127-129, 2016. Available from: <http://onlinelibrary.wiley. com/doi/10.1111/vde.12296/abstract;jsessionid=FF475B680261D 4AE7D87E27832722265.f03t01>. Accessed: Sept. 01, 2016. doi: $10.1111 /$ vde. 12296.

PROCTOR, H.C. Feather mites (Acari: Astigmata): ecology, behavior, and evolution. Annu Rev Entomol, v.48, p.185-
209, 2003. Available from: <http:/www.annualreviews.org/ doi/10.1146/annurev.ento.48.091801.112725>. Accessed: Dec. 08, 2016. doi: 10.1146/annurev.ento.48.091801.112725.

REZENDE, L.C. et al. Mites affecting hen egg production: some considerations for Brazilian farms. Cienc Rural, v.43, n.7, p.1230-1237, 2013. Available from: <http://www.scielo.br/ scielo.php?script $=$ sci_arttext\&pid $=$ S0103-84782013000700014>. Accessed: Oct. 15, 2016. doi: 10.1590/S0103-84782013005000088.

REZENDE, L.C. et al. Epidemiology of Megninia spp. in laying flocks from the State of Minas Gerais, Brazil. Rev Bras Parasitol Vet, v.24, n.2, p.198-203, 2015. Available from: $<$ http://www.scielo.br/scielo.php?script=sci_arttext\&pid $=$ S1984-29612015000200198 $>$. Accessed: Oct. 10, 2016. doi: 10.1590/S1984-29612015027.

SCHOULER, C. et al. Diagnostic strategy for identifying avian pathogenic Escherichia coli based on four patterns of virulence genes. J Clin Microbiol, v.50, n.5 p.1673-1678, 2012. Available from: <http://jcm.asm.org/content/50/5/1673>. Accessed: Oct 27, 2016. doi: 10.1128/JCM.05057-11.

STATACORP. 2011. Stata Statistical Software: Release 12. College Station, TX: StataCorp LP.

TUCCI, E.C. et al. Infestação por Megninia spp. em criação industrial de aves produtoras de ovos para consumo. Arq Inst Biol, v.72, n.1, p.121-124, 2005. Available from: <http://www. biologico.sp.gov.br/docs/arq/V72_1/tuccil.PDF $>$. Accessed: Dec. 10, 2016 